\title{
State-Owned Enterprise Partnership Program as a Form of Corporate Social Responsibility to Small and Medium
} Enterprises

DOI: https://doi.org/10.47175/rissj.v2i4.334

\section{| Muhammad Yusrizal |}

Universitas Muhammadiyah

Sumatera Utara, Indonesia

muhammadyusrizal@umsu.ac.id

\section{ABSTRACT}

State-Owned Enterprises (SOEs) have a very important role in the implementation of the national economy in order to realize the welfare of the people. SOEs are seen as having a strategic role in fostering and developing private and cooperative businesses. The government through its regulations has mandated SOEs to participate in assisting the government in implementing the development policies that have been outlined, this is as mandated in Article 88 of Law no. 19 Year 2003 on SOEs, which in the article instructs SOEs to set aside a parcel of their net benefit for the reason of cultivating little businesses and cooperatives as well as cultivating the community around the company. The existence of the provisions of Article 88 means that SOEs are not only looking for profit, but also must play an active role in developing and fostering small businesses and cooperatives, so SOEs will have the responsibility Corporate social responsibility that can be sued is the same as other private companies in Indonesia.

KEYWORDS

Partnership program; State-Owned Enterprises (SOEs); MSE actors

\section{INTRODUCTION}

State-Owned Enterprises (hereinafter referred to as SOEs) have strategic roles and functions, as implementers of public services, balancing the strengths of the large private sector and helping the development of small businesses/cooperatives. Thus the vitality of the existence of a SOEs and to provide a strong legal basis for the business space of SOEs, the government together with the DPR approved and ratified Law no. 19 Year 2003 on State-Owned Enterprises (hereinafter referred to as the regulation of SOEs) which came into force on June 19, 2003.

The purpose and intent of the establishment of SOEs is very noble and deserves a large, very strategic portion of the economic system in Indonesia, moreover, SOEs are also a critical source of state income within the shape of different sorts of charges, profits and privatization continues (Wibisono, 2007).

Community empowerment, including micro and small enterprises, is not only the duty and responsibility of the central and local governments, but also the duty and responsibility of the business world, as explained in Article 7 of Law no. 20 year 2008 on Micro, Small and Medium Enterprises, which states that: "The business world (corporation) plays a role in fostering a conducive business climate, namely in terms of financing, offices and foundation, commerce data, organizations, trade permitting, commerce openings, exchange advancement and organization support."

The advancement of miniaturized scale and little endeavors (hereinafter referred to as SMEs) by SOEs has been carried out since the issuance of Government Regulation no. 3 year 1983 concerning Procedures for Guidance and Supervision of Service Companies (Perjan), Public Companies (Perum) and Limited Liability Companies (Persero). At that 
time, the cost of developing small businesses was charged as a company expense. With the issuance of the Decree of the Minister of Finance No. 1232/KMK.013/1989 dated November 11, 1989 concerning Guidelines for Guiding Weak Economic Entrepreneurs and Cooperatives through State-Owned Enterprises, the coaching fund is provided from a partial allowance of $1 \%-5 \%$ of profit after tax, the name of the program at that time was better known as "Pegelkop Program" and subsequently in 1994, changed to the Development of Small Business and Cooperatives (PUKK Program), based on the Decree of the Minister of Finance No. 316/KMK.016/1994, dated 27 June 1994 concerning Guidelines for the Development of Small Businesses and Cooperatives through the Utilization of Funds from the Profit Section of State-Owned Enterprises.

The form of concern for SOEs based on the Regulation of the Minister of State for SOEs mentioned above can be translated into 2 (two) programs, namely:

1. Partnership Program could be a program to move forward the capacity of little businesses to gotten to be solid and autonomous through the utilize of stores from the benefit share of SOEs.

2. Community Improvement Program could be a program for engaging the social condition of the community by SOEs through the use of SOEs' share of profits.

The implementation of the partnership program in SOEs is intended to support and encourage MSEs to become foster partners, this will further facilitate MSEs in obtaining soft loans. The Partnership and Community Development Program (PCD) is a program that is synonymous with corporate social responsibility or in other words PCD is a form of corporate social responsibility (Rahmatullah and Kurniati, 2011).

For MSE actors, the main problem in carrying out their business is the capital sector. This causes people to be unable to use banking services to develop their business, so that for these small entrepreneurs their business cannot develop or even stop altogether. Borrowing and borrowing money itself has been done for a long time in people's lives who have known money as a means of payment. The activity of borrowing and borrowing money is something that is crucial to bolster the improvement of financial exercises and to progress their standard of living (Bahsan, 2007).

Therefore, the SOE Partnership Program can be utilized by MSE actors who are located close to the company's work location. The convenience provided to MSEs in obtaining capital loans from SOEs is relatively simpler, cheaper, and faster when compared to loans through banks.

\section{RESEARCH METHODS}

The nature of this research is analytical descriptive. The sort of inquire about utilized is standardizing juridical. Normative juridical research is research that is intended and carried out by using a study of legislation and other written legal materials related to this writing (Sunggono, 2007).

Within the standardizing legitimate inquire about strategy, to be specific legitimate inquire about conducted by looking at library materials or secondary materials, the sort of information in this inquire about is secondary information. (Soekanto and Mamuji, 1985) Secondary data consists of:

a. Primary legal materials, in the form of various laws and regulations, official documents that have authority related to the association program of State-Owned Enterprises).

b. Secondary legal materials, namely all legal materials which are publications of unofficial documents including books, scientific works. 
c. Tertiary legitimate materials, to be specific materials that give or clarify essential lawful materials and auxiliary legitimate materials, such as common lexicons, lawful word references, logical diaries, magazines, daily papers and the internet.

To obtain objective and verifiable research results and the results can be accounted for, the research will use data collection tools.

After all secondary data is obtained, it will then be sorted so that legal materials that regulate the data obtained will be analyzed inductively-deductively. The method chosen is so that the normative symptoms that are considered can be analyzed from various aspects in depth and are integrated from one aspect to another.

\section{RESULTS AND DISCUSSION}

\section{The Regulation of State-Owned Enterprise Partnership Program}

\section{The History of State-Owned Enterprise}

The first form of SOEs that ever existed in Indonesia, although not owned by the Indonesian government, was Vereenigde Oost-Indische Compagnie (VOC) which was formed and owned by the Government of the Dutch East Indies in 1602.

During the 1940-1950 era, where the corporate sector was still underdeveloped, business activities were dominated by foreign companies and a small group of entrepreneurs, so that business sectors related to the livelihoods of many people were not managed according to their objectives. ndeavors to make strides the welfare of all Indonesian individuals as mandated in the preamble to the 1945 Constitution are a constitutional duty for all components of the nation. Further elaboration in Article 33 of the 1945 Constitution states that:

1. The economy is organized as a joint effort based on the run the show of family relationship.

2. Generation branches that are imperative to the state and influence the job of the individuals are controlled by the state.

3. The soil and water and the riches contained in that are controlled by the state and utilized for the most noteworthy thriving of the people;

4. The national economy is organized based on financial vote based system with the standards of harmony, productivity with equity, supportability, natural knowledge, freedom, and by keeping up the adjust of advance and national financial unity.

Based on this, the Government of the Republic of Indonesia considers it necessary to increase the control of all national economic forces, either through sectoral regulations, or through state ownership of certain business units with the aim of providing the maximum benefit for the prosperity of the people. The Indonesian government realized the need for a reliable corporate sector to build the national economy, so that in turn it formed statecontrolled enterprises/corporations/state-owned companies originating from the nationalization of ex-Dutch companies.

SOEs has special characteristics that are not owned by other business entities which are formulated as: "A organization clothed with the control of government but had the adaptability an activity of a private endeavor". This is where the efficacy of SOEs institutions lies (Anaraga, 2002: 2)

Since 1969, the role of SOEs in supporting national development has increased in line with the implementation of development. However, during the New Order era, the performance of SOEs was very concerning. The company's performance is considered inadequate, as can be seen in the low profit earned compared to the invested capital. 
The purpose and intent of the establishment of SOEs is very noble and deserves a large, very strategic portion of the economic system in Indonesia, moreover, SOEs are also a noteworthy source of state income within the frame of different sorts of charges, profits and privatization continues (Wibisono, 2007).

The provisions in Article 1 number (1) of the SOEs Law have defined SOEs as: "A business entity whose capital is wholly or most of the capital is possessed by the state through coordinate support beginning from isolated state resources".

Meanwhile, the aims of SOEs as alluded to in Article 2 paragraph (1) of the SOEs Law are:

a. Contribute to the improvement of the national economy;

b. The interest of profit;

c. Organizing open benefits within the shape of giving high-quality and satisfactory products and/or services to fulfill desires of numerous people.

d. Gotten to be a pioneer in commerce exercises;

e. Take an interest effectively

SOEs is a public enterprise, namely as an element of the government (public) and as an element of business (enterprise). As a public enterprise there are 3 (three) meanings contained in it, namely: public purpose, public ownership and public control. From the three meanings, public purpose is the core of the SOEs concept. This public purpose is described as the government's desire to achieve development goals (social, political and economic) for the welfare of the nation and state. It is in this connection that SOEs are often described as tools for achieving national goals. (Banji Anaraga, 2002: 2-3).

\section{State-Owned Enterprise Partnership Program}

The definition of a partnership program according to the provisions of Article 1 point (6) of the Regulation of the Minister of State for the Minister of State-Owned Enterprises No.: PER-02/MBU/04/2020, is: "The SOEs organization program, hereinafter alluded to as the association program, may be a program to move forward the capacity of little businesses to be solid and autonomous."

The existence of a partnership program implemented by The definition of a partnership program according to the provisions of Article 1 point (6) of the Regulation of the Minister of State for the Minister of State-Owned Enterprises No.: PER-02/MBU/04/2020, is: "The SOE association program, hereinafter alluded to as the association program, may be a program to progress the capacity of little businesses to be solid and autonomous."

The existence of a partnership program implemented by SOEs is a commitment from the government to foster and develop small businesses. The government in this case remains consistent with the plan of its work program in developing MSEs. This is evidenced by the policies and developments aimed at industry/small businesses by the government through the concepts that have been created, namely: is a commitment from the government to foster and develop small businesses. The government in this case remains consistent with the plan of its work program in developing MSEs. This is evidenced by the policies and developments aimed at industry/small businesses by the government through the concepts that have been created, namely: is a commitment from the government to foster and develop small businesses. The government in this case remains consistent with the plan of its work program in developing MSEs. This is evidenced by the policies and developments aimed at industry/small businesses by the government through the concepts that have been created, namely:

1. The linkage system of the adoptive father of business partners.

2. Sale of shares in large healthy companies to cooperatives. 
3. Required State-Owned Enterprises (SOEs) to set aside funds for coaching of $1-5 \%$ of net profits.

4. Assigning banking institutions to allocate credit funds for small businesses and cooperatives as much as $20 \%$ of the portfolio of loans disbursed.

5. Supply of Liquidity Credit from Bank Indonesia to banks to finance most of the need for credit funds for members of primary cooperatives. (Harimurti, 2001: 120)

In carrying out its business activities, SOEs is not only limited to seeking profit, but also has a commitment and strives to move forward the welfare of the community where the company runs its operations. It is intended that the company can continuously develop.

The concept of corporate social duty includes organization duties between the government, community asset educate, as well as neighborhood communities. This partnership is a shared social responsibility among stakeholders (Bertens, 2000). Corporate social responsibility was born from public pressure on companies that tend to ignore social and environmental responsibilities such as doing various environmental damage, exploitation of natural resources and labor in carrying out their business activities. The concept and practice of corporate social responsibility at this time has shown new symptoms as a corporate methodology that can goad and stabilize trade development for the long term (Asniwaty, 2010).

The corporate social responsibility program itself is a form of community development program development that seeks to empower the community through the capabilities and potentials possessed by the community. In this community development, the community is a participant as well as a beneficiary of development (Ariefianto, 2015).

The company is the party that gains large profits in the utilization of these resources, while the community is the party that will actually bear the negative externalities, both direct and indirect (Hadi, 2011).

The review in Article 2 of the SOEs Law in conjunction with Article 66 paragraph (1) has regulated the implementation of corporate social responsibility. Even for the implementing regulations, a Ministerial regulation has been issued with respect to the organization program of state-owned endeavors with little businesses and the natural advancement program. The basis for regulating the partnership program and community development, where the implementation of the partnership program was carried out with the basic philosophy, namely:

a. Obligation.

SOEs are required to carry out PCD which is financed from the provision of a portion of the company's net profit.

b. Social tasks.

The implementation of PCD is a social task considering that this task is not the core business of SOEs.

c. Accountable.

SOEs are required to keep separate books

d. Corporate Action.

The implementation of PCD is a corporate action, in which other than PCD organs.

Corporate social duty is an imperative handle in controlling the costs and benefits of trade exercises from partners both inside (specialists, partners and financial specialists) and remotely (open administrative teach, community individuals, respectful society bunches and other companies). 
According to the Indonesian CSR study circle, Corporate social responsibility is a genuine effort of a business entity, to play down the negative affect and maximize the positive affect of its operations on all partners within the financial, social and natural domains in arrange to attain feasible improvement objectives. This definition implicitly means inviting companies to be serious in their efforts to provide benefits for their presence for mankind today. While minimizing the negative impact is part of the effort to supply benefits within the future (Suparman, 2013).

\section{State-Owned Enterprise Partnership Program as a Form of Corporate Social Responsibility to Small and Medium Enterprises}

As a manifestation of the mandate of Article 2 and Article 88 of the SOEs Law, since 1989 SOEs have been providing guidance to small entrepreneurs, while the Community Development Program was only implemented in 1999. This is an effort by the government to provide guidance through partnership programs and the provision of assistance working capital advances within the shape of capital credits with relatively small interest.

However, the guidelines regarding the implementation of the program were only ratified in 1994, at which time the Minister of Finance Decree No. 316/KMK.016/1994, dated June 27, 1994 concerning Guidelines for the Development of Small Businesses and Cooperatives (PUKK) through the use of funds from the profit share of SOEs.

To expand the scope of SOE's social responsibility to the community around the company, PCD based on the Decree of the Minister of State-Owned Enterprises No.: KEP236/MBU/2003, dated June 17, 2003 on the Partnership Program of SEOs with SMEs and the Community Development Program and later changed again with the issuance of Minister of State-Owned Enterprises Regulation No.: Per-05/MBU/2007 concerning Partnership Programs of SEOs with Small Businesses.

Furthermore, to provide a better operational basis to increase accountability for the implementation of SOEs Partnership Program with small businesses and, it is deemed necessary to review the regulations regarding SOEs partnership program with small businesses and the environmental development program, the Minister of State-Owned Enterprises Regulation No: The PER-07/MBU/05/2015 was revoked.

The Organization Program could be a program to progress the capacity of little businesses within the shape of advances, both for business capital and the purchase of production support equipment so that little businesses gotten to be solid and free. Whereas the Community Advancement Program could be a program for empowering social conditions of the community for the reason of giving benefits to the community within the commerce zone of SOEs concerned.

The existence of a company is expected to encourage the wheels of the economy in an area, which brings the community (community) to a higher standard of living. Thus, there must be a balance of community benefits with business benefits that can be obtained from a mixture of pure philanthropy and business sponsorship approach which gives birth to strategic philanthropy. The government acts as a catalyst in this process. Community development programs must be based on coordination and agreement between companies as funders to fulfill community needs and the government as regulator (A.B. Susanto, 2007: 69-70).

Efforts to foster and develop MSEs carried out by SOEs cover the areas of generation and preparing, showcasing, human assets and innovation. National and economic financing and the public includes bank loans, loans from non-bank financial institutions, venture capital, loans from the profit share of SOEs, grants and other types of financing. The 
financing is guaranteed by government and/or private borrowing institutions, in the form of bank credit financing guarantees, profit sharing guarantee financing, and other financing delivery (Bintang and Dahlan, 2000).

In order for the objectives of implementing the partnership program to be achieved, based on the Regulation of the Minister of State the Minister of State-Owned Enterprises No.: PER-09/MBU/07/2015, namely:

a. Establish a Partnership Program unit and Community Development Program;

b. Prepare SOP;

c. Prepare Work Plan and Budget;

d. Conduct evaluation and selection of business feasibility and determine prospective Foster Partners;

e. Prepare and distribute Partnership Program;

f. Monitoring and coaching the Foster Partners;

g. Administering coaching activities;

h. Keeping books;

i. Submit reports to the Minister.

The priority in implementing the partnership program by SOEs is aimed at small business actors who do not yet have the ability to access banking. The partnership program can be carried out for small businesses that do not have business links or those that have business links with SOEs, but are strived towards the realization of business linkages. As one of the coaching and development efforts given to small businesses is to set aside a portion of SOEs profits to small business actors through partnership programs.

In principle, all types of productive business activities from all economic sectors such as: industry, trade, agriculture, plantations, fisheries, services and other sectors (including cooperatives) can be partnered and financed by SOEs through partnership programs. The provisions in Article 3 of the Regulation of the Minister of State for the Minister of StateOwned Enterprises No.: PER-09/MBU/07/2015 that is Small Businesses that can take part within the Organization Program.

The provisions as referred to in paragraph (1) letter f, do not apply to small businesses that have just been formed or have been established at the initiative of the State-Owned Enterprises Trustees as part of the Partnership Program for SOEs.

The source of funding for SOEs in carrying out the partnership program comes from the company's net profit after deducting taxes, the amount of which will be determined by the GMS/Minister. Which matters have been expressly regulated in Article 8 of the Ministerial Regulation of the Minister of State-Owned Enterprises No.: PER-09/MBU/07/2015, namely:

(1) Sources of Funds for the Partnership Program and BL Program are as follows:

(2) The remaining funds for the Partnership Program and BL Program for the previous financial year will become the source of funds for the following year.

(3) The Association Program and BL Program stores beginning from the stipend for after-tax benefits as alluded to in section (1) letter a, might be stored into the Association Program and BL Program support account no afterward than 45 (forty five) days after the assurance of the sum of the finance assignment.

(4) Funds for the Partnership Program and BL Program can only be placed in deposits and/or demand deposits at state-owned banks.

(5) Bookkeeping of Partnership Program and BL Program reserves is carried out in understanding with pertinent bookkeeping guidelines. 
Regarding the form of assistance provided by SOEs to small business actors, namely within the frame of credits to back working capital, uncommon advances to fund the require for reserves for the usage of the trade exercises of the cultivated accomplices, the burden of coaching to fund instruction, preparing, promoting, advancements and others related to progressing efficiency of cultivate accomplices. Furthermore, small business actors who have received loans will become foster partners of the SOEs. The provisions regarding the form of loans that will be provided by SOEs to small business actors are as stipulated in the provisions of Article 9 of the Minister of State-Owned Enterprises Regulation No.: PER-02/MBU/04/2020.

For the mechanism for distributing partnership program funds by SOEs companies to their fostered partners, in this case, small business actors are required to submit their application in order to become SOEs fostered partners by attaching the conditions specified in Article 11 of the Ministerial Regulation of the Minister of Owned Enterprises. Country No.: PER-02/MBU/7/2017.

It is different for the distribution of partnership program funds for micro and small enterprises by special SOEs, where in the provisions of Articles 12A, 12B, 12C and 12D of the Regulation of the Minister of State for the Minister of State-Owned Enterprises No.: PER-02/MBU/7/2017, has regulated specifically specifically for SOEs Trustees may provide interest-free loans or awards of Association Program reserves to SOEs within the field of budgetary administrations particularly set up for the advancement and trengthening of the people's economy, hereinafter referred to as special SOEs. In the implementation of the provision of interest-free loans and/or grants, the Board of Directors of the StateOwned Enterprises (SOEs) of the Trustees may receive approval from the GMS/Minister.

In the next stage, before the process of distributing partnership program funds to small business actors, SOEs will first select the application file submitted by the prospective foster partner. The selection of incoming application files is carried out using a channeling system, namely by:

1) Conduct a survey on prospective fostered partners by taking into account the facts in the field and written in the proposal as well as seeking supporting data and information for decision making.

2) Checking the validity of administration and credit analysis, whether it is appropriate to be given a loan and how much loan will be given.

3) Selecting prospective fostered partners in order of priority and availability of funds and paying attention to the allocation of available funds.

If in the selection of application files and surveys carried out by prospective fostered partners it is deemed appropriate to receive assistance, it will proceed to the stage of signing the agreement between SOEs and the fostered partners, at which stage the funds are distributed to the fostered partners.

Awareness of the fostered partners in repaying loans given to them on time is very necessary, this is because SOEs will use the funds to then be channeled back to other prospective fostered partners who need assistance for their business capital, so that the funds continue to roll and can be felt benefits for other small business actors.

The quality of loans given to fostered partners will be assessed based on the timeliness of repayment of loan principals and loan administration services, therefore each State Owned Enterprise (SOEs) is required to make a classification of the quality of the loan quality of the partnership program funds. The regulation on the quality of partnership program fund loans has been explicitly regulated in the Ministerial Regulation of the Minister of State-Owned Enterprises No.: PER-09/MBU/07/2015, namely: 
Classification of Loan Quality is determined as follows:

a. Current, is installment of foremost installments and advance organization administrations on time or there's a delay in installment of foremost installments and/or advance organization administrations no afterward than 30 (thirty) days from the due date of installment installments;

b. Substandard, in case there's a delay in installment of foremost installments and/or credit organization administrations that have surpassed 30 (thirty) days;

c. Far fetched, in the event that there's a delay in installment of foremost installments and/or credit organization administrations that have surpassed 180 (one hundred and eighty) days;

d. Misfortune, in the event that there's a delay in installment of central installments and/or credit administrati. The classification of loan quality carried out by the fostering SOEs is made as an effort to monitor the level of non-performing loans from their fostered partners and at the same time see the level of awareness of the fostered partners towards the obligations that must be carried out, namely loan repayment.

In addition, the classification of loan quality is made so that SOEs can take actions by means of Loan Recovery, namely by rescheduling (rescheduling) or adjusting requirements (reconditioning), but the fostered partners must meet predetermined criteria, namely in good faith or cooperative, the fostered partner's business is still running and has business prospects and still has the ability to pay installments.

\section{CONCLUSION}

The partnership program implemented by SOEs is a mandate from Article 2 and Article 88 of Law Number 19 year 2003 on State-Owned Enterprises, which requires all SOEs companies to set aside profit after tax of a maximum of $2 \%$ (two percent) or the proceeds of credit intrigued on stores and request stores from organization program reserves after deducting the company's working costs.

The Partnership Program implemented by SOEs is one of the manifestations of social responsibility that must be implemented as a form of the company's real contribution to the surrounding community, where SOEs companies are not only faced with responsibilities that are based on the company's profit / profit, but also must pay attention to social and environmental responsibility.

In addition, the partnership program run by SOEs is a commitment from the government to provide guidance and development to micro and small business actors. Therefore, the existence of the partnership program is the attitude of the government that remains consistent with the plan of its work program to develop micro and small business actors.

\section{Suggestion}

The government, in this case, is expected to remain consistent in fostering and developing small businesses through partnership programs run by SOEs. In addition, SOEs in providing guidance to small business actors in the partnership program continue to optimize their performance so that the benefits can really be felt. Furthermore, the role of the government is needed to be able to provide legal certainty and protect SOEs in carrying out partnership programs. This is very necessary so that in the implementation of the 
distribution of the partnership program carried out by SOEs it is not said to be an illicit bank, because it involves financial traffic activities to the general public.

\section{REFERENCES}

Anaraga, Panji. (2002). BUMN, Swasta dan Koperasi, Jakarta: Pusataka Jaya

Ariefianto, Lutfi. (2015). Program Corporate Social Responsibility (CSR) PT Semen Indonesia Tbk Dan Dampaknya Terhadap Keberdayaan Masyarakat, Jurnal Pancaran, $4(2)$

Asniwaty, Besse. (2010). Evaluasi Pelaksanaan Coorporate Sosial Responsibity (CSR) PT. Pupuk Kaltim, Jurnal Eksis, 6(1)

Bahsan, M. (2007). Hukum Jaminan dan Jaminan Kredit Perbankan Indonesia, Jakarta: Raja Grafindo Persada

Bertens, K. (2000). Pengantar Etika Bisnis (Seri Filsafat Atmajaya : 21), Yogyakarta: Kanisius

Bintang, Sanusi \& Dahlan. (2000). Pokok-pokok Hukum Ekonomi dan Bisnis, Bandung: Citra Aditya

Hadi, Nor. (2011). Corporate Social Responsibility, Yogyakarta: Graha Ilmu

Hafsah, Mohammad Jafar. (2000). Kemitraan Usaha, Konsepsi Dan Strategi, Jakarta: Pustaka Sinar Harapan

Harimurti. (2001). Manajemen Usaha Kecil, Yogyakarta: BPFE Yogyakarta, 2001.

Law Number 19 of 2003 concerning State-Owned Enterprises.

Law Number 20 of 2008 concerning Enterprises, Micro, Small and Medium, State Gazette of the Republic of Indonesia No. 93 of 2008.

Rachmat, Budi. (2004). Modal Ventura, Jakarta: Ghalia Indonesia

Rahmatullah and Trianita Kurniati. (2011). Panduan Praktis Pengelolaan Corporate Social Responsibility, Jogjakarta: Samudra Biru

Regulation of the Minister of State-Owned Enterprises No. PER-09/MBU/07/2015 concerning the Partnership Program and the Community Development Program for State-Owned Enterprises.

Regulation of the Minister of State-Owned Enterprises No.: PER-03/MBU/12/2016 concerning Amendments to Regulation of the Minister of State-Owned Enterprises No.: PER-09/MBU/07/2015 concerning Partnership Programs and Community Development Programs for State-Owned Enterprises,

Regulation of the Minister of State-Owned Enterprises No. PER-02/MBU/7/2017 concerning the Second Amendment to the Regulation of the Minister of State-Owned Enterprises Number PER-09/MBU/07/2015 concerning the Partnership Program and the Community Development Program for State-Owned Enterprises.

Regulation of the Minister of State-Owned Enterprises No. PER-02/MBU/04/2020 concerning the Third Amendment to the Regulation of the Minister of State-Owned Enterprises No.: PER-09/MBU/07/2015 concerning the Partnership Program and the Community Development Program for State-Owned Enterprises.

Rudito, Bambang et al. (2004). Corporate Social Resonsibility: Jawaban Bagi Model Pembangunan Indonesia Masa Kini, Jakarta: Indonesia Center for Sustainable Development (ICSD)

and Melia Famiola. (2007). Etika Bisnis dan Tanggung Jawab Sosial Perusahaan di Indonesia, Bandung: Rekayasa Sains

Soekanto, Soerjono and Sri Mamuji. (1985). Penelitian Hukum Normatif (Suatu Tinjauan Singkat), Jakarta: Rajawali Pers 
Sunggono, Bambang. (2007). Metodologi Penelitian Hukum, Jakarta: PT Raja Grafindo Persada

Suparman. (2013). Corporate Social Responsibility: Bentuk Tanggung Jawab Sosial dan Kepedulian Perusahaan Dengan Masyarakat, Jurnal Interaksi, 2(2)

Susanto, A.B. (2007). Corporate Social Responsibility, Jakarta: The Jakarta Consulting Group

The 1945 Constitution of the Republic of Indonesia

Wibisono, Yusuf. (2007). Membedah Konsep \& Aplikasi Corporate Social Responsibility (CSR), Gresik: Fascho Publishing 